\title{
Global Aid in the Water Sector: A Descriptive Analysis of International Development Effectiveness
}

\author{
Andrew Hargrove ${ }^{1}$ \\ ${ }^{1}$ Stony Brook University, United States \\ Correspondence: Andrew Hargrove, Stony Brook University, United States.
}

Received: December 13, 2018

Accepted: January 22, $2019 \quad$ Available online: February 1, 2019

doi:10.11114/ijsss.v7i2.3874

URL: https://doi.org/10.11114/ijsss.v7i2.3874

\begin{abstract}
This study analyzes the intent and effectiveness of international development aid through a content/trend analysis of over 42,000 aid projects in the water supply and sanitation sector. The water sector is a vital and understudied component of international development that is rife with internal contradictions. On the one hand, access to water is rapidly increasing cross-nationally, but over 700 million still lack improved access to water. On the other hand, renewable freshwater resources per capita are rapidly decreasing, and annual freshwater withdrawals are steadily increasing. These concurrent issues lead to water stress and decreased freshwater sustainability, which in turn affects global political, ecological, and health issues. To address these issues, national governments and multinational aid agencies have been lending to the water supply and sanitation sector since 1950 . This study assesses the trends in international aid over the past 65 years for their intent and effectiveness in solving global water and development issues. The results have implications for the development effectiveness of nations' and organizations' aid and calls for social scientists to investigate well-being and environmental impacts simultaneously in all sectors of development.
\end{abstract}

Keywords: international development, sustainable development, aid, access to water, water stress, environment, content analysis

\section{Introduction}

\subsection{Background}

Despite discourse concerning the global water crisis, the world is currently confronting at least two water crises: a developmental crisis concerning populations who lack access to water, and an environmental crisis regarding water scarcity and freshwater resource depletion (Barlow 2014). These two social-ecological events directly threaten lives, as well as the socio-economic and political structures that underpin our species' existence (Galaz et al. 2011; Homer-Dixon et al. 2015). While over 700 million people lack access to water, affecting women and children in poor rural areas and crowded urban slums the greatest, renewable freshwater resources per capita are rapidly declining globally, while annual freshwater withdrawals steadily increase (Black and King 2009). These issues overlap, creating multifaceted problems for nations, including widespread disease, drought, famine, environmental damage, ecological disasters, and political instability (Shiva 2002; Taylor and Sonnenfeld 2017). Therefore, efforts must be made to identify solutions that tackle the interrelated problems of water access, quality, and scarcity concurrently (Bakker 2014; Mukheibir 2010; Taylor and Sonnenfeld 2017).

Multilateral agencies (i.e. World Bank, UNICEF, and the UN) and national governments have been pouring money into the water supply and sanitation sector since 1950. Approximately $\$ 370$ billion have been sent to bolster water development and mitigate water stress (AidData 2017). These projects fund many water and sanitation needs, but not all issues are funded equally. While water issues do not constitute a zero-sum game, resources directed at specific issues may inadvertently siphon resources from other goals (Mukheibir 2010; Shiva 2002; Taylor and Sonnenfeld 2017). Metabolic rift theory predicts that the consumption of resources for capitalism and human use often has detrimental effects on environmental health and ecosystems (Foster 1999). For instance, aid for developmental water issues, such as increasing water access, often funds projects building dams or digging boreholes and wells (AidData 2017). These loans increase the quantity and quality of water for the communities that they serve. However, boreholes and wells utilize groundwater (water stored in aquifers); this water, sometimes referred to as fossil water, is replenished slowly, and often takes thousands of years to accumulate (Black and King 2009; Shiva 2002). The steady aid from lending agencies and 
national governments over the past 65 years has, at least in part, led to the over-withdrawal and sometimes complete depletion of aquifers, leading to water stress and concerns over environmental sustainability (Barlow 2014; Taylor and Sonnenfeld 2017). Furthermore, large dams reroute rivers, flood ecosystems, increase water temperature, and negatively impact human communities and endangered animals both upstream and downstream (Black and King 2009; Shiva 2002). These two examples illustrate how projects meant to benefit human development can lead to environmental degradation and over-withdrawal of freshwater (Linton 2010; Pahl-Wolstl 2015).

On the other hand, aid for environmental conservation and sustainability often puts limits on water withdrawal and halts the advancement of new projects for dams, boreholes, and infrastructure that increase water withdrawal (AidData 2017; Shiva 2002). These limits can lead to water stress that disproportionately affects poor rural and urban slum dwellers, leading to unsanitary practices, poor health, and increased mortality, especially among infants and children (Linton 2010; Taylor and Sonnenfeld 2017). In this way, water sector aid for the environment can lead to decreased access to water for the populations that need it the most.

Continued aid to the water supply and sanitation sector is necessary to attenuate these crises (Mukheibir 2010). However, allocating resources without proper analysis of past trends and current issues may exacerbate existing problems, especially if projects lack an appreciation for the complexity of the issues at hand (Swiss 2017). The recently adopted sustainable development discourse advocates tackling social, environmental, and economic issues simultaneously (Sachs 2015). In addition, recent critiques of aid and development criticize the lack of collaboration between different actors among aid practitioners (Huitema et al. 2009; Tacconi and Tisdell 1993). Taking a holistic view on any developmental issue should help ameliorate conflict over scarce resources (Mukheibir 2010). While the possible conflict between issues of water access and water scarcity have been pointed out previously and studies questioning the intent and effectiveness of global aid have been performed, there has yet to be a systematic analysis of the actual content of the global aid being sent to the water supply and sanitation sector.

I perform a content and trend analysis to determine where the billions of dollars of water sector aid are going, the intent of the funded projects, and which water crisis (either or both) they attend to. I aim to analyze the intent and effectiveness of global aid to the water supply and sanitation sector and whether calls for holistic, collaborative, polycentric aid with monitoring and follow-up are being heeded in global water aid. This analysis has implications for the development effectiveness of aid and calls for social scientists and practitioners to investigate well-being and environmental impacts simultaneously. Theoretical and practical integration of these issues is key to address concurrent water crises. I analyze over 42,000 water supply and sanitation sector aid projects from AidData using content analysis and linguistic software (Antconc). I utilize all aid to the water supply and sanitation sector over the past 65 years, identifying four major themes in water supply loans: human development, economic development, technical expertise, and environmental concerns. The analysis offers a breakdown by lender, receiver country, year, funding amount, and project theme. Through the analysis, I argue that practitioners and researchers rarely treat development needs and environmental concerns concurrently.

\subsection{Literature Review}

\subsubsection{Water Access}

Improving water and sanitation access is an essential development component. Sociology of development literature finds water and sanitation to be two of the most important determinants for desirable development outcomes. The benefits include decreased infant mortality (e.g., Fink et al. 2011; Hertz et al. 1994; Shandra et al. 2012), decreased child mortality (e.g., Desai and Alva 1998; Fink et al. 2011; Shandra et al. 2011), decreased maternal mortality (e.g., Coburn, Restivo, and Shandra 2015; Hertz et al. 1994), increased life expectancy (e.g. Hertz et al. 1994), and decreased prevalence of diarrheal diseases, typhoid, cholera, ascariasis, trachoma, dracunculiasis, and hookworms (e.g., Montgomery and Elimelech 2007; World Bank 2003).

Bilateral, multilateral, and local and international organizations echo the importance of increased access. In the 1980's, improving water quality and access became a major development goal, represented by the UN's "International Decade for Clean Drinking Water" (Barlow 2014). More recently, in 2000, the millennium development goals (MDGs) charged global development agencies the task of decreasing by half the populations without access to both improved water sources and improved sanitation facilities. Today, countless NGO's, activists, governments, and multinationals collaborate to increase access and to achieve the sustainable development goal 6 of universal water access. Figure 1 illustrates that since 1990, we have been extremely successful at increasing water access. However, the remaining 700 million lacking access will be the most difficult to reach, as they often live in rural areas with little or no natural water sources, urban slums with inadequate infrastructure, and regions with the greatest water stress (Barlow 2014). The remaining 700 million represent the global crisis of water access. The disease burden from unsafe water sources alone causes hundreds of thousands of deaths per year (Fink et al. 2011). Humanitarian efforts and global aid must continue to combat this crisis. 


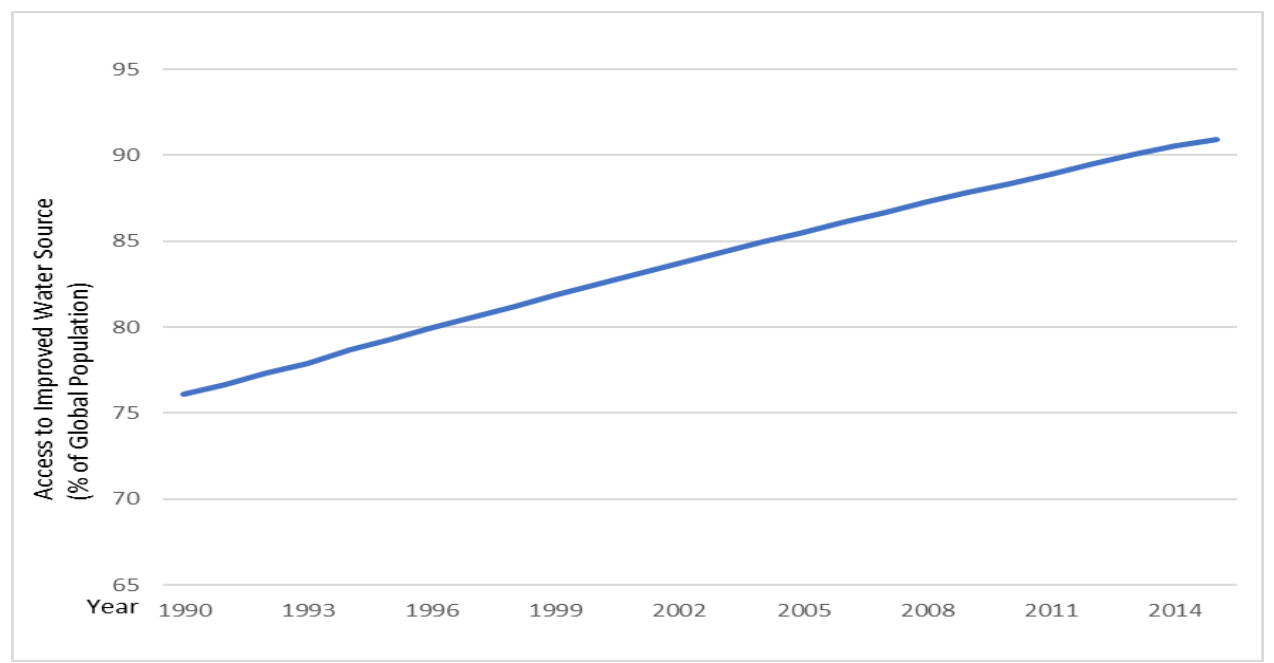

Figure 1. Global access to improved water source (\% of population), 1990 - 2014

\subsubsection{Water Scarcity}

At around the same time development efforts began focusing on providing communities with improved water and sanitation, scientists began collecting data on water availability globally (World Bank 2017). Figure 2 shows the dramatic decline in renewable freshwater resources per capita from 1960 to 2014. This decline of per capita renewable water resources seems to correspond to the increase of freshwater withdrawals accompanying global development, industrialization, and population growth. These trends, and the growing environmental movements that accompany it, suggest another global water crisis, the crisis of water scarcity. While hundreds of thousands of children die every year due to water related illnesses such as diarrhea, trachoma, and dracunculiasis, the risk is greater for humanity if we deplete our finite water resources (UNICEF and World Health Organization 2015).

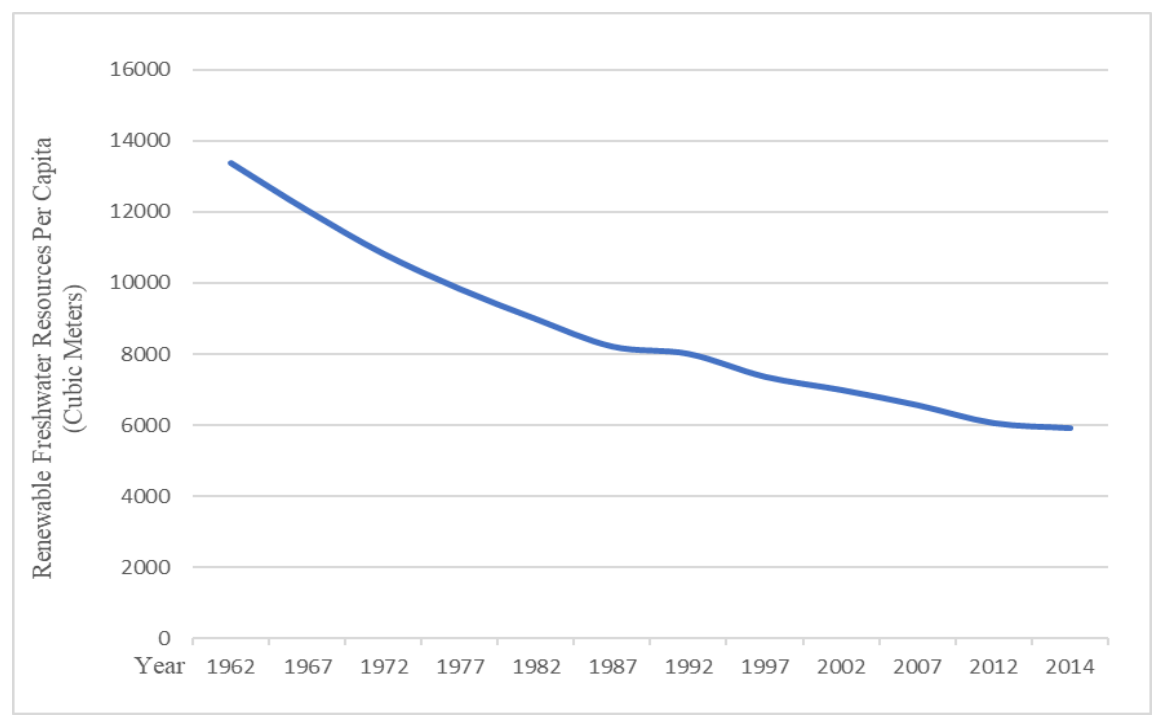

Figure 2. Global renewable freshwater resources per capita, 1962 - 2014

Water resources utilized for consumption, production, and agriculture are being taxed to their limit (Barlow 2014; Black and King 2009). Luckily, the water cycle can renew our water resources through evaporation and recharge. Unfortunately, water renewal assumes that water is contained to its watershed, and in an interconnected global world, water is often 'shipped' virtually (water used to create goods, food, and products) as well as in the form of bottled water or pipelines shipping water to far off locations. Therefore, trade of goods and services removes water that would have been renewed through the hydrologic cycle (Black and King 2009). In other words, the hydrologic cycle, even when groundwater is replenished, is incapable of keeping up with human consumption, production, and agriculture (Pimentel et al. 1997). The shipment of virtual water and real water through water bottles and pipelines disturbs the ecological balance of watersheds, leading to desertification, biodiversity loss, streams, river, and lakes drying up, and resources 
dwindling (Barlow 2014).

The increasing demands on freshwater resources threaten the supply of water for food production, drinking, bathing, and other basic human needs (Pimentel et al. 1997). In addition to these losses, construction of super large dams, a popular development strategy, reroutes rivers, floods communities and large areas of land, dispossesses millions, and destroys wildlife (Black and King 2009; Feldman 2012). Large dams also cut off downstream populations from vital water, increasing water stress and aggravating cross-border tensions (Black and King 2009).

Water shortages already currently affect major areas within India, the Middle East, Northern Africa, and East Asia, and are expected to negatively impact nearly all countries in the next 20 years (Black and King 2009). Despite awareness of water scarcity issues, freshwater resources per capita are declining across essentially every nation (World Bank 2017). The aforementioned problems represent an environmental water crisis without precedent. Global development agencies, NGO's, and national governments have begun efforts to curb the environmental impacts of development, agriculture, and population growth. However, unless a holistic position is adopted, development and aid may exacerbate the already water stressed regions of the world.

\subsection{Research Question and Hypotheses: What Is the Purpose of International Aid and Is It Effective?}

As detailed above, while water access is increasing, freshwater resources per capita are rapidly decreasing, and annual freshwater withdrawals are steadily increasing (Black and King 2009). This is a serious issue for development scholars and practitioners. Unfortunately, solutions are often contradictory, and therefore the problems may be difficult to address when not considered together (Barlow 2014). Metabolic rift theory asserts that ecological crises can often arise when consumption under capitalism and related resource demands destroy and create ecological imbalances (Clausen and Clark 2005; Foster 1999). I extend this theory to the concurrent water crises of water access and water scarcity. One would expect that as access to water and withdrawals for agriculture and manufacturing increases, especially as more people enjoy consumption at the rate of North Americans, water stress and scarcity will increase, leading to desertification and ecological imbalances, including loss of habitats and species. Conversely, if we reduce our stress on the water system to conserve water and create a sustainable system of water use, then populations, especially those already marginalized today, may have even lower access to water (Barlow 2014). Therefore, it seems imperative to find innovative ways to address these problems simultaneously. Based on efforts in aid due to the MDGs, I believe most aid projects, especially in the past 15 years should be focused on increasing water access and improving water for health. Additionally, based on criticisms in the literature, especially in theories of Integrated Management of Water Resources (IMWR) (see Mukheibir 2010), I also believe that water aid projects rarely address environmental and human needs concurrently. IMWR researchers claim that existing development aid lacks holistic, polycentric projects with proper monitoring and follow-up.

Hypothesis 1: There will be far more human development water supply and sanitation sector projects than environmental water supply projects.

Hypothesis 2: The proportion of projects that address human development and environmental concerns simultaneously will be relatively small.

While ostensibly used to help nations in need, the intention of global development aid is heavily debated. Swiss (2017) outlines three distinct discourses concerning the purpose of international aid. He suggests that, on the one hand, international aid is altruistic, reserved for helping those most in need (Lumsdaine 1993; Opeskin 1996), and on the other hand, aid is seen as a tool powerful sender nations can use for trade and policy bargaining, or other selfish motives (Alesina and Dollar 2000). Aside from this classic dichotomy, Swiss (2017) asserts that social/economic relations, such as democracy, political instability, colonial legacy, and integration into global norms, may underlie international aid transactions (Carment, Samy and Prest 2008; Feeny and McGillivray 2009).

A content analysis of aid practices may help to reconcile these competing explanations. While it is very difficult to determine the intentions and motivations of lending agencies and national governments, it is possible to analyze the rhetorics they use to discuss their aid projects. The rhetoric of development projects serves as a public organizational justification for actions taken. An analysis of aid project descriptions can determine if the rhetorics frame the lending agency/government as altruistic, self-motivating, or normative. If aid is altruistic, then the amount of aid a nation receives should be proportional to their need, in other words, water sector aid should be concentrated in nations with the greatest water stress (Swiss 2017). I add to this by arguing that altruistic international aid should have higher levels of complexity, as taking a holistic approach is the most effective method for addressing all aspects of a nation's water needs.

Hypothesis 3: If international aid is altruistic, then water sector aid should be proportional to water needs in receiver nations. 
Hypothesis 4: If international aid is altruistic, then water sector projects should have higher levels of complexity

Contrarily, if international aid is a tool used for the self-interest of lender nations and organizations, aid would be concentrated in democratic countries with high levels of trade with lenders (Swiss 2017). This may be due to lender nations paying lip service to the problems of nations they are pursuing trade relationships with. In addition to Swiss's hypothesis, I would also expect that if aid is self-interested, water sector projects should have less complexity and fewer overlapping themes, as projects will be focused on the political and economic goals of the sender, not necessarily the needs of the receiver.

Hypothesis 5: If international aid is selfish, then water sector aid should be concentrated in nations that are democratic and nations with higher levels of trade.

Hypothesis 6: If international aid is selfish, then water sector projects should have lower levels of complexity.

Finally, Swiss (2017) suggests that international aid may be a vehicle of embeddedness in a global network. In that case, we would expect that aid would be concentrated among nations with the highest embeddedness in world society indicated by their non-governmental organization (NGO) memberships (Swiss 2017). In addition, following world society theorists (Schofer and Hironaka 2005), I assert that international aid aimed at global embeddedness should fund projects aimed at human rights and women's empowerment, with an increasing focus on the environment over time, as NGOs proliferate these global scripts and norms.

Hypothesis 7: If international aid is about global embeddedness, then water sector aid should be concentrated in nations with the most NGOs.

Hypothesis 8: If international aid is about global embeddedness, then water sector projects should address human rights, women's empowerment, and environmentalism

In addition to the debates concerning the intention of international aid, common questions in this literature also surround how well sender nations and organizations fund projects that address important themes rather than just incorporate pressing development issues for institutional survival or "window dressing." These themes vary from concerns about water for health, human rights, and access to concerns over economic growth, water management, and water scarcity. Mukheibir (2010) identifies a lack of synergy and collaboration between three distinct discourses in the water development literature: sustainable development (that aims to tackle social, environmental, and economic issues), Integrated Management of Water Resources (IMWR, which focuses on the technical expertise and equipment necessary to solve local water issues), and climate change adaptation (which deals with coping, preparing, and adapting for climate change). The goals of these discourses can be overlapping and complementary but are often contradictory and may lead to conflict (Mukheibir 2010). While it is important to recognize the conflict between these overarching discourses, I argue that even within themselves, these discourses are often contradictory with major debates concerning the "right way" to solve the water crises. This analysis focuses on these divisions in the sustainable development discourse.

While the sustainable development may appear cohesive from an outside perspective, it is rife with internal struggles. Sustainable development's explicit goal is to tackle social, environmental, and economic issues simultaneously (Sachs 2015). To be successful, our management of the world's water resources requires complexity, collaboration, and a turn towards holistic projects (Mukheibir 2010; Pahl-Wostl et al. 2012). Focusing on only one aspect of sustainable development's three pronged goals may lead to problems for the other aspects (York, Rosa, and Dietz 2003). Pahl-Wostl and colleagues (2012) suggest that "economic and institutional development often focuses on and leads to fulfilling needs of the human population at the expense of the environment (24)." I argue that because different factors lead to increases in social, environmental, and economic issues, that projects that only address one of these is not only not helpful to the other two goals but may even be harmful.

A content analysis can help us to observe the patterns and trends in international aid over the past several decades. There has been an increasing call for international water aid that is polycentric and redistributive (Gibson 2012; Pahl-Wostl et al. 2012), collaborative (Huitema et al. 2009; Pahl-Wostl et al. 2012), holistic (Huitema et al. 2009; Mukheibir 2010), and inclusive of long term monitoring and critical reflection (Gleick 2003; Meinzen-Dick 2007). The current analysis may help reveal whether international water aid has indeed been improving in these areas. In addition to the hypotheses concerning the intention of international aid, I have developed three hypotheses assessing the effectiveness of international water supply and sanitation aid to answer the aforementioned calls for holistic solutions.

Hypothesis 9: If projects have become more collaborative and polycentric, we would expect that the number of projects addressing and working with local issues has increased.

Hypothesis 10: Holistic water projects should address multiple themes (economic, social, and environmental), rather than just one or two of these themes. 
Hypothesis 11: If international water development has been focusing on long term monitoring and critical reflection, we would expect there to be an increase in projects mentioning monitoring, evaluation, follow-ups, and reflection.

Both the purpose and effectiveness of international aid are heavily debated. Researchers question whether lending institutions are altruistic, selfish, or a mixture of the two. Researchers also raise concerns about which issues international development aid is addressing, be it social, economic, or environmental. Finally, there has been a call for international aid that is collaborative, holistic, and self-reflexive. This analysis aims to shed light on these debates by interrogating past aid practices to identify patterns and trends. This novel approach will provide answers based on empirical evidence in lieu of theoretical guessing. While imperfect, I hope that this analysis will be able to contribute to the multiple debates concerning international development aid. I add to the debate by introducing a new dataset allowing for an assessment of broad trends and descriptive qualitative analyses of projects. While the water supply and sanitation sector is the focus of this analysis, the results should have implications for international aid in general, and the debates concerning its intentions and effectiveness.

\section{Data and Methods}

To investigate aid practices in the water supply and sanitation sector, I utilize content analysis (computational and analog for inductive and deductive theme formation). This allows me to address what issues water sector aid addresses, as well as patterns of aid over time. To uncover themes and trends in international aid practices, I use all water supply and sanitation sector loans available from AidData with listed amounts in US dollars and project long descriptions. AidData contains the most comprehensive dataset on bilateral (country to country) and multilateral (multinational agencies to country) loans and grants in existence. While not exhaustive, AidData has more information on lending and aid than any other data source. AidData contains 72,243 projects in the water supply and sanitation sector. Removing all projects with no long description of the project's purpose and projects with $\$ 0$ in commitment resulted in a dataset containing 42,060 water sector projects between 1950 and 2014.

Both inductive and deductive processes were used to analyze the $42,000+$ projects. First, 200 randomly selected projects were read for possible themes. Through this process, four overarching themes were identified: human development, economic development, technical expertise, and environmental concerns. Words/phrases indicative of these themes were recorded to identify a preliminary word list for textual analysis software. Python was then used to clean and parse the data to be uploaded into a linguistic analysis software (Antconc). I systematically scoured Antconc's generated table of commonly used words to identify missed words/phrases during my manual read through the 200 randomly selected articles, allowing for the inclusion of many foreign words missed in the preliminary analysis (e.g. pauvret, saneamiento, kwalitatief, etc.). To ensure that all words on my lists accurately reflect the themes they are meant to represent, I manually verified the context of every word in the theme lists, allowing the exclusion of words that did not accurately reflect the themes of the project. The complete lists for all four themes are included in Table 1.

Table 1. Word lists for four water supply and sanitation sector project themes

\begin{tabular}{|c|c|c|c|}
\hline Human Development & Economic Development & Environmental Concerns & Technical Expertise \\
\hline access* & budget* & acces durable & advis* \\
\hline acess* & business* & agriculture durable & capabilit* \\
\hline approvis* & commercial enterprise* & ambiental* & coop* \\
\hline assain* & consult* & anthrop* & coordinat* \\
\hline borehole* & corporat* & biodivers* & database \\
\hline clean water & credit & changing climate & governance \\
\hline commun* & earning* & climate change & TC agg* \\
\hline comun* & econom* & climate variability & technical \\
\hline disease* & expenditure* & climatiq* & train* \\
\hline distribu* & feasib* & conserv* & \\
\hline drink* & financ* & developpement durable & \\
\hline educ* & fiscal & durable au & \\
\hline empoderamiento & fondo* & durable $\mathrm{d}^{*}$ & \\
\hline empower* & gdp & durable $\mathrm{e}^{*}$ & \\
\hline equitab* & incom* & durable $\mathrm{f}^{*}$ & \\
\hline eradicat* & industrial growth & durable $\mathrm{g}^{*}$ & \\
\hline health & invest & durable i* & \\
\hline hospital* & investe* & durable $1^{*}$ & \\
\hline humanit* & investiisement* & durable par & \\
\hline hyg* & investing & durable qui & \\
\hline immun* & investisement* & ecosyst* ${ }^{*}$ & \\
\hline kwalitatief & investm* & envior* & \\
\hline latrin* & investo* & environ* & \\
\hline malaria & macroecon* & et durable & \\
\hline
\end{tabular}




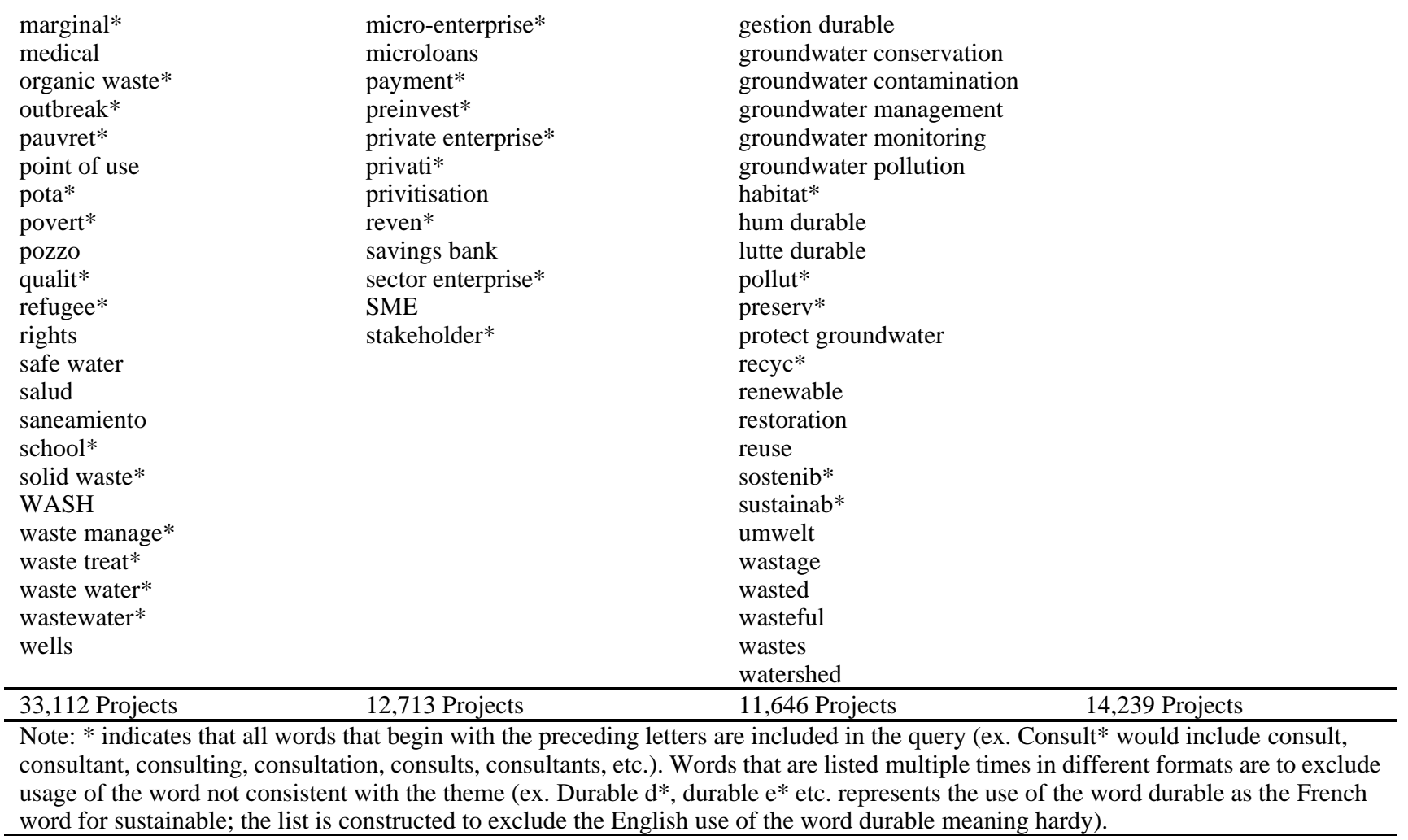

Antconc linguistic analysis was used to analyze each complete word list, resulting in a list of every usage of the words in each theme list. Using this technique, each individual project was coded 1 for a given theme if its long description contained words from the corresponding theme list, and a 0 if not. From this, I could identify the rhetoric of every water supply project from 1950 to 2014, in addition to the complexity of each project (represented by the total number of themes covered by the project, between 0 and 4 ). Several robustness and verification tests were done to ensure that data were a valid representation of each water sector lending project, that each theme was correctly accounted for, and that the word lists reflected each theme. This process enabled me to identify all combinations of themes used in every project, and the corresponding receiver nation, amount of USD, year, and type.

Computational linguistic analysis was also utilized to identify key words that represent the different hypotheses suggested by the literature and theories discussed above. To represent embeddedness in world society, keywords NGO*, human right*, and well-being* were used. The keywords local*, communa*, communit*, grassroot*, collab*, and polycentric* were used to identify projects that were collaborative and polycentric. Finally, to test the hypothesis of whether water sector aid has included monitoring and reflection, I used the key words monit*, evalu*, follow-up*, and upkeep*. Summaries of these results can be found in the results section.

Quantitative data from existing datasets were also used as additional analyses. Water stress data was collected from the World Resources Institute. The water stress index accounts for the average exposure of water users in a country to water stress calculated as the ratio of total withdrawals to total renewable supply (World Resources Institute 2017). Data on democracy (civil liberties and political rights) were obtained from Freedom House (2017). A democracy index was created by taking the average score of civil liberties and political rights for each country. The International Yearbook of Associations provided me with data on International Non-Governmental Organizations (INGOs). This variable represented the total number of INGOs a country has at least one member for (Schofer and Hironaka 2005). Finally, trade data, the total trade in a country as a percentage of total GDP was accessed through the World Bank (2017).

\section{Analysis}

\subsection{Descriptives}

Figure 3 shows the distribution of water supply and sanitation projects over time between 1950 and 2013. As I demonstrated in figure 3, there has been a drastic increase in projects originating around the year 2000. This trend is explained by the MDGs. Target 7C of the MDGs tasked the world with decreasing the proportion of the population without access to an improved water source and sanitation facility by half. This target offered legitimacy to organizations to fund previously unpopular projects in the water supply sector, increasing total projects per year from 
500-1000 in the 1990's to $2000-4000$ in the 2000's and nearly 6000 per year in the early 2010's. However, while we know that there has been a major uptick in funding for water supply projects, there has yet been no analysis of the types of projects being funded, why specific types of projects are more popular than others, if projects take a more holistic approach or are more focused on one goal, and the effectiveness of all this aid. This analysis aims to begin to explore some of these questions to obtain a deeper understanding of water supply aid. Most ( 95\%) water sector projects have been funded by multinationals (i.e. World Bank, UNICEF), North America (United States and Canada), Europe (with France, Germany, and Spain being the most prolific), and East Asia (almost entirely Japan and South Korea). However, these trends are inconsistent over time. From 1950 through the 1980's, funding in the water supply sector was almost entirely from multinationals and the Middle East. This changed in the 1990's and into the 2000's beginning with Europe and North America and followed by all other lenders into the MDG era. Europe became such prolific funders during the MDG era that they surpassed multilaterals in total projects despite starting nearly 40 years later.

Trends for receiver countries are less pronounced. The 1950's through the 1990's saw a diverse group of project beneficiaries centered around Sub-Saharan Africa, Asia, and the Americas. The onset of the MDG era ushered in a period where all regions of the world began to receive water supply project aid. However, aid was still primarily focused on Africa, Asia, and the Americas. These trends are heartening as it seems from an aggregate view that water supply projects are going where they are needed the most. Those regions that are receiving the most aid are those that have the lowest proportion of access to improved water sources and have the greatest environmental water stress.

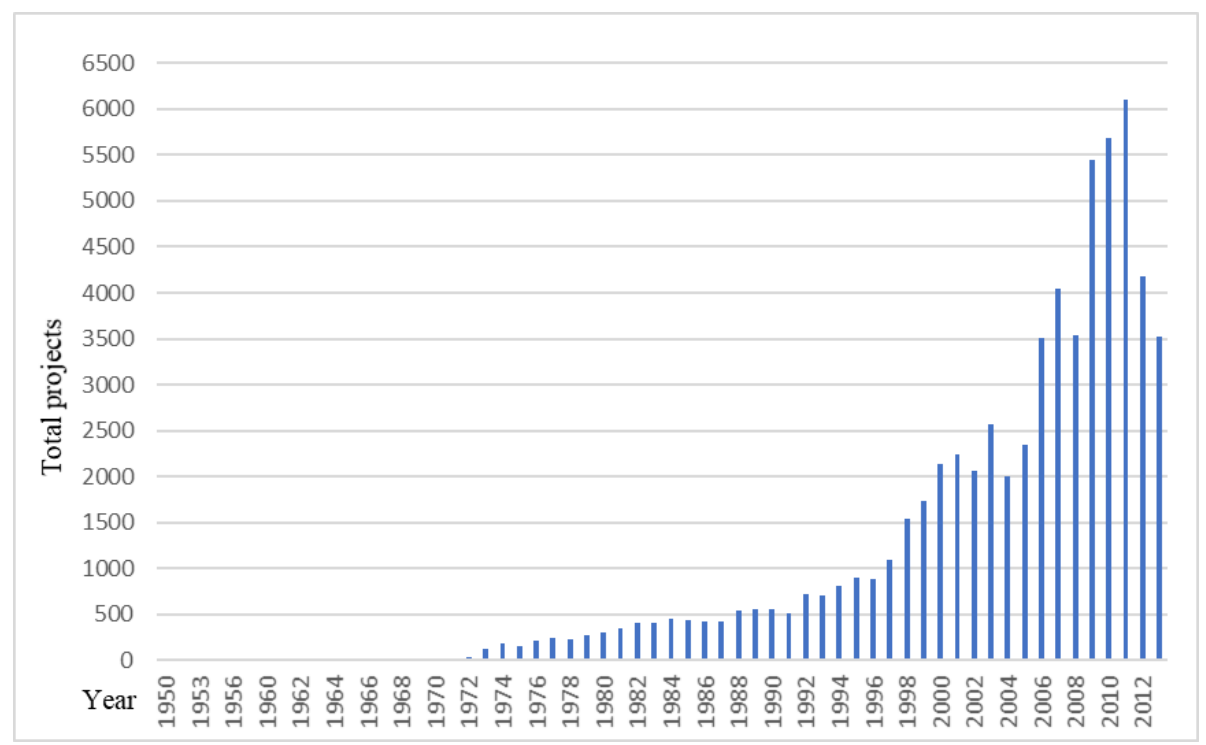

Figure 3. Water supply and sanitation sector project count, 1950 - 2013

To delve deeper into the types of water projects that have received aid in the past, I utilized content analysis to analyze each of the project's descriptions. Using both inductive and deductive methods, I identify four main themes in water supply funding: human development, environmental concerns, economic development, and technical expertise. I will now discuss these themes in depth. A summary of the analysis and all 11 hypotheses can be found in table 2 .

Table 2. Summary of Analysis for 11 Hypotheses

\begin{tabular}{|c|c|c|c|c|c|c|}
\hline & Project themes & $\begin{array}{l}\text { Number of } \\
\text { projects }(\%)\end{array}$ & Calls for action & $\begin{array}{l}\text { International } \\
\text { development } \\
\text { effectiveness }\end{array}$ & $\begin{array}{l}\text { Statistical } \\
\text { difference }\end{array}$ & Solutions \\
\hline $\begin{array}{l}\text { Hypothesis } 1 \text { : } \\
\text { there will be } \\
\text { more human } \\
\text { than } \\
\text { environment } \\
\text { water aid }\end{array}$ & $\begin{array}{l}\text { Human \& } \\
\text { Environment }\end{array}$ & $\begin{array}{l}\text { Human } \\
41,164 \\
(97.9 \%) \\
\text { Environment } \\
12,207 \\
(29.02 \%)\end{array}$ & $\begin{array}{l}\text { Current water aid } \\
\text { focuses heavily on } \\
\text { human } \\
\text { development }\end{array}$ & $\begin{array}{l}\text { High. Most projects } \\
\text { address human } \\
\text { needs. Access has } \\
\text { increased by } 15 \% \\
\text { globally over past } \\
25 \text { years }\end{array}$ & N/A & $\begin{array}{l}\text { Future projects should } \\
\text { continue to solve access } \\
\text { issues, but also tackle } \\
\text { environmental } \\
\text { scarcity/sustainability and } \\
\text { technical \& economic } \\
\text { needs of nations }\end{array}$ \\
\hline $\begin{array}{l}\text { Hypothesis 2: } \\
\text { aid that } \\
\text { addresses } \\
\text { human AND } \\
\text { env. is rare }\end{array}$ & $\begin{array}{l}\text { Human \& } \\
\text { Environment }\end{array}$ & $\begin{array}{l}\text { Projects that } \\
\text { address both } \\
1,365 \\
(3.25 \%)\end{array}$ & $\begin{array}{l}\text { Address both } \\
\text { human and } \\
\text { environmental } \\
\text { issues } \\
\text { simultaneously }\end{array}$ & $\begin{array}{l}\text { Poor. Very few aid } \\
\text { projects contain } \\
\text { both human and } \\
\text { environment } \\
\text { together }\end{array}$ & N/A & $\begin{array}{l}\text { Future projects must } \\
\text { address human and } \\
\text { environmental needs } \\
\text { concomitantly for holistic } \\
\text { solutions }\end{array}$ \\
\hline
\end{tabular}




\begin{tabular}{|c|c|c|c|c|c|c|}
\hline $\begin{array}{l}\text { Hypothesis } 3 \text { : } \\
\text { water aid } \\
\text { should be } \\
\text { proportional to } \\
\text { water needs }\end{array}$ & $\begin{array}{l}\text { All themes } \\
\text { Altruistic aid }\end{array}$ & N/A & $\begin{array}{l}\text { Altruistic aid } \\
\text { should be } \\
\text { proportional to } \\
\text { country needs }\end{array}$ & $\begin{array}{l}\text { Poor. Statistical } \\
\text { analysis finds that } \\
\text { aid is actually } \\
\text { negatively } \\
\text { correlated with } \\
\text { water stress }\end{array}$ & $\begin{array}{l}\text { Water stress } \\
\text { and aid: } \\
\text { Coefficient } \\
-25.85 ; \mathrm{p}<.05\end{array}$ & $\begin{array}{l}\text { Aid should be focused } \\
\text { where need is greatest }\end{array}$ \\
\hline $\begin{array}{l}\text { Hypothesis 4: } \\
\text { altruistic aid } \\
\text { should have } \\
\text { higher levels of } \\
\text { complexity }\end{array}$ & $\begin{array}{l}\text { Combine all } \\
\text { themes } \\
\text { Altruistic aid }\end{array}$ & $\begin{array}{l}2 \text { themes } \\
(29.61 \%) \\
3 \text { themes } \\
(14.88 \%) \\
4 \text { themes } \\
(6.59 \%)\end{array}$ & $\begin{array}{l}\text { Holistic projects } \\
\text { are more likely to } \\
\text { address the } \\
\text { complex issues of } \\
\text { water }\end{array}$ & $\begin{array}{l}\text { Fair. Most aid } \\
\text { projects only } \\
\text { engage in one } \\
\text { theme. True holistic } \\
\text { engagement is rare }\end{array}$ & N/A & $\begin{array}{l}\text { Holistic solutions to water } \\
\text { issues should take human, } \\
\text { environmental, economic, } \\
\text { and technical issues into } \\
\text { consideration } \\
\text { simultaneously }\end{array}$ \\
\hline $\begin{array}{l}\text { Hypothesis 5: } \\
\text { water aid } \\
\text { should be } \\
\text { concentrated in } \\
\text { democratic } \\
\text { nations with } \\
\text { high trade } \\
\text { levels }\end{array}$ & $\begin{array}{l}\text { All themes } \\
\text { Self-serving aid }\end{array}$ & N/A & $\begin{array}{l}\text { Self-serving aid } \\
\text { lends more to } \\
\text { democratic nations } \\
\text { with high intl. } \\
\text { trade }\end{array}$ & $\begin{array}{l}\text { No support. } \\
\text { Statistical analysis } \\
\text { finds that } \\
\text { democracy and } \\
\text { trade are negatively } \\
\text { correlated with aid } \\
\text { projects }\end{array}$ & $\begin{array}{l}\text { Democracy and } \\
\text { aid: } \\
\text { Coefficient } \\
-31.41, \mathrm{p}<.001 \\
\text { Trade and aid: } \\
\text { Coefficient } \\
-1.73, \mathrm{p}<.001\end{array}$ & $\begin{array}{l}\text { To solve issues of scarcity } \\
\text { and access, a nation's } \\
\text { politics and trade } \\
\text { relationships should be } \\
\text { overlooked and focused on } \\
\text { need }\end{array}$ \\
\hline $\begin{array}{l}\text { Hypothesis 6: } \\
\text { self-serving aid } \\
\text { should have } \\
\text { lower levels of } \\
\text { complexity }\end{array}$ & $\begin{array}{l}\text { All themes } \\
\text { Self-serving aid }\end{array}$ & $\begin{array}{l}0 \text { themes } \\
(8.62 \%) \\
1 \text { theme } \\
(40.31 \%)\end{array}$ & $\begin{array}{l}\text { Self-serving aid } \\
\text { will focus on less } \\
\text { complex projects }\end{array}$ & $\begin{array}{l}\text { Poor. Most water } \\
\text { aid focuses on just } \\
\text { one aspect of the } \\
\text { water crisis, calls } \\
\text { for holistic, } \\
\text { complex aid } \\
\text { unheeded }\end{array}$ & N/A & $\begin{array}{l}\text { Future projects must } \\
\text { engage with more themes } \\
\text { to address the complexity } \\
\text { of water issues }\end{array}$ \\
\hline $\begin{array}{l}\text { Hypothesis } 7: \\
\text { water aid } \\
\text { should be } \\
\text { associated with } \\
\text { NGOs }\end{array}$ & $\begin{array}{l}\text { All themes } \\
\text { Global scripts }\end{array}$ & N/A & $\begin{array}{l}\text { NGO's should } \\
\text { permeate and } \\
\text { increase } \\
\text { effectiveness of aid }\end{array}$ & $\begin{array}{l}\text { High. NGO } \\
\text { membership } \\
\text { increases the } \\
\text { amount of water aid } \\
\text { received }\end{array}$ & $\begin{array}{l}\text { NGO's and aid: } \\
\text { Coefficient } \\
1.39, \mathrm{p}<.001\end{array}$ & $\begin{array}{l}\text { NGO's show evidence of } \\
\text { being associated with } \\
\text { greater aid in developing } \\
\text { nations }\end{array}$ \\
\hline $\begin{array}{l}\text { Hypothesis 8: } \\
\text { water aid } \\
\text { should address } \\
\text { human rights } \\
\text { and women's } \\
\text { empowerment }\end{array}$ & $\begin{array}{l}\text { All themes } \\
\text { Global scripts }\end{array}$ & $\begin{array}{l}\text { Human rights } \\
620(1.5 \%) \\
\text { Women's } \\
\text { rights } \\
162(<1 \%)\end{array}$ & $\begin{array}{l}\text { Global scripts } \\
\text { (human rights, } \\
\text { etc.) should direct } \\
\text { the agenda of aid } \\
\text { projects }\end{array}$ & $\begin{array}{l}\text { Poor. While human } \\
\text { needs are being } \\
\text { addressed in most } \\
\text { projects, global } \\
\text { scripts do not seem } \\
\text { to have a large } \\
\text { influence }\end{array}$ & N/A & $\begin{array}{l}\text { Very few projects engage } \\
\text { with the global scripts of } \\
\text { human rights, well-being, } \\
\text { and women's } \\
\text { empowerment }\end{array}$ \\
\hline $\begin{array}{l}\text { Hypothesis 9: } \\
\text { local } \\
\text { collaborative } \\
\text { aid has } \\
\text { increased over } \\
\text { time }\end{array}$ & $\begin{array}{l}\text { All themes } \\
\text { cooperation }\end{array}$ & $\begin{array}{l}\text { Cooperation } \\
623(1.5 \%) \\
\text { Polycentric } \\
0(0 \%) \\
\text { Local } \\
4101(9.8 \%)\end{array}$ & $\begin{array}{l}\text { Collaborative and } \\
\text { polycentric aid } \\
\text { should take local } \\
\text { issues into } \\
\text { consideration }\end{array}$ & $\begin{array}{l}\text { Poor. A critical } \\
\text { amount of aid does } \\
\text { not engage in } \\
\text { cooperation with } \\
\text { local populations }\end{array}$ & N/A & $\begin{array}{l}\text { Future projects need to } \\
\text { consider the concerns of } \\
\text { local populations and have } \\
\text { more collaboration at all } \\
\text { levels of governance }\end{array}$ \\
\hline $\begin{array}{l}\text { Hypothesis } 10 \text { : } \\
\text { calls for } \\
\text { holistic aid } \\
\text { should lead to } \\
\text { projects with } \\
\text { higher } \\
\text { complexity }\end{array}$ & $\begin{array}{l}\text { All themes } \\
\text { Holistic }\end{array}$ & $\begin{array}{l}\text { Holistic } \\
4 \text { themes } \\
2,528 \\
(6.59 \%)\end{array}$ & $\begin{array}{l}\text { Holistic aid } \\
\text { addresses water } \\
\text { concerns in } \\
\text { multiple themes }\end{array}$ & $\begin{array}{l}\text { Poor. Although } \\
\sim 6.5 \% \text { of aid } \\
\text { includes all themes, } \\
\text { close analysis finds } \\
\text { that very few } \\
\text { actually address } \\
\text { water issues } \\
\text { holistically }\end{array}$ & N/A & $\begin{array}{l}\text { Very few projects take a } \\
\text { holistic approach to aid, } \\
\text { future solutions must } \\
\text { correct this, calls for } \\
\text { complex holistic problem } \\
\text { solving are not being } \\
\text { heeded }\end{array}$ \\
\hline $\begin{array}{l}\text { Hypothesis 11: } \\
\text { water aid } \\
\text { should have } \\
\text { mechanisms for } \\
\text { monitoring and } \\
\text { evaluation }\end{array}$ & $\begin{array}{l}\text { All themes } \\
\text { Monitoring }\end{array}$ & $\begin{array}{l}\text { Monitoring } \\
1,804(4.3 \%) \\
\text { Evaluation } \\
1,023(2.4 \%)\end{array}$ & $\begin{array}{l}\text { To improve future } \\
\text { projects, } \\
\text { monitoring and } \\
\text { evaluation of past } \\
\text { projects is needed }\end{array}$ & $\begin{array}{l}\text { Poor. Less than } 5 \% \\
\text { of projects describe } \\
\text { a monitoring or } \\
\text { oversight } \\
\text { mechanism. Only } \\
76 \text { projects discuss } \\
\text { any sort of } \\
\text { follow-up }\end{array}$ & N/A & $\begin{array}{l}\text { Monitoring, oversight, and } \\
\text { evaluation are nearly } \\
\text { absent in past water aid } \\
\text { projects. Learning from } \\
\text { past failures and successes } \\
\text { is critical for improving } \\
\text { future aid }\end{array}$ \\
\hline
\end{tabular}

\subsection{Human Development}

Projects with a human development theme address issues including, but not limited to, increasing water and sanitation 
access, human rights, health, education, hygiene, and eradication of poverty. The computational linguistic analysis yielded 41,164 projects containing human development keywords, accounting for over $95 \%$ of all projects. Human development was by and large the most common theme in water supply projects, lending major support to hypothesis 1 that there will be far greater human development projects than environmental projects.

One example of a typical human development loan is the Ibadan Water Supply II project to Nigeria in 1991. This project "aims at improving the health aspects of the town of Ibadan by increasing the supply of reliable drinking water" (AidData 2017). Project 50052963 funded the "construction of a system of drinking water" for Jupiro of the Canton Loja in Ecuador. To supply 2 million residents in 14 major towns in the Democratic Republic of the Congo was the objective of project 635666. Other projects were directed towards refugees, indigenous, or poor populations. Human development projects also included education concerning water supply, hygiene, sanitation, health, and water related illnesses. Some human development projects went to increase the quantity of water available to a town, city, or municipality by drilling boreholes, extending piping, digging wells, or building aqueducts; others went to increase the quality of water by building or maintaining water treatment plants, cleaning existing sources, or educating populations about point of use water treatment. The one thing that these projects had in common is that their purpose was the improvement in the quality of life, well-being, and health of the populations they served.

From 1990 - 2013, the period with the greatest total water supply aid, the proportion of the world without access to improved water decreased by $15 \%$, bringing water to nearly 1 billion people. It is possible that this deduction over the past 25 years is partly due to these human development projects. Thanks to the MDGs, the world has embarked on a concerted effort to bring safe water to all people.

\subsection{Environmental Water Sector Aid}

Projects with an environmental theme were the least common type of project. These projects included aid for conservation, restoration, ecosystem maintenance, sustainability, contamination and pollution cleanup, and climate change preparation or prevention. While projects with environmental themes have grown in absolute numbers over time with nearly 400 in the 1980 's to almost 5000 in the 2000 's, as a proportion of all water supply and sanitation sector aid, environmental projects have decreased from over 50\% of projects between 1950 and 2000 to under 30\% following 2000 . From this we can deduct that although the MDG era encouraged massive amounts of increased lending to the water supply sector after 2000, the proportion of aid going towards the environment actually decreased. This may be especially concerning given the increased awareness and attention to climate change and water shortages/stress over the past several decades. Some research has even suggested that the human development loans that are excelling at providing populations with greater access to water may be accelerating drought, ecosystem destruction, overconsumption, and water stress around the world (Barlow 2014; Shiva 2002).

Despite being the least funded theme among all water sector aid, environmental projects are vital during this time of increased water stress and freshwater depletion. For example, the Metropolitan Water Intake Project in South Korea aimed to "control the effects of population... in a section of the Han River..., which (has) become polluted from domestic and industrial wastes" (AidData 2017; project 1964949). Other projects address water stress, climate change, desertification, and sustainable practices in water use.

Projects for environmental concerns are the least common (12,207 projects; 1/4 of all projects). Human development, on the other hand, is the most prolific theme among the loans (Over $90 \%$ of all projects address human development in one way or another). Projects that addressed economic development or technical expertise each represented approximately one third of total projects. One out of every three loans combined at least two of the four themes in their project. However, the incidence of human development and environmental concerns in the same project only occurred in 5\% of all loans. It appears both academics and practitioners alike rarely treat development needs and environmental concerns together. These findings support hypothesis 2 that there will be relatively few projects addressing human development and environmental concerns simultaneously.

\subsection{Technical and Economic Projects}

Approximately $2 / 3$ of all projects $(27,771 ; 66 \%)$ had a technical aspect while about $1 / 3$ of projects $(14,289 ; 34 \%)$ had at least one economic aspect. Technical projects focused on providing advisors, technical assistance, advice for governance, access to datasets and scientists, and training on proper use of technologies. Projects with an economic theme focused on balancing budgets, improving or integrating business, industrial growth, loans and microloans, payment of debt, enterprise, and fiscal responsibility. Over time, the proportion of projects with a technical aspect has remained fairly constant, with $\sim 2 / 3$ of lending in each decade having some technical aspect. I suspect that this is the case due to the importance of training, advising, and information in all types of loans. On the other hand, like environmental aid, while projects with an economic focus have increased in absolute numbers over time, the proportion of aid with an economic theme has decreased over time, from over $90 \%$ pre-1990, to around $75 \%$ in the 1990 's, and 
finally decreasing to about $1 / 3$ of all loans in the 2000's. I suspect that this is partially due to criticisms of lending (especially from multinationals such as the World Bank and IMF) not focusing on the developmental and human needs of populations.

An example of a project with a technical aspect can be found in the North-West Rural Development II project, stating that it is "providing institutional support... training services and applied research; continued assistance to the project management office" (Aiddata 2017; project 13). An example of an economic project states "the project aims to put in place a sustainable commercial supply of affordable MITs, to train farmers in the new methodology, and to provide them with access to microloans to initiate the diversification of their agricultural production. It also aims to strengthen existing marketing cooperatives and to establish new marketing cooperatives and collection centres." (Aiddata 2017; project 50057403). It is vital for future water aid to continue emphasizing the technical and economic aspects of water project feasibility to improve the expertise of end-users, the proper implementation of safety and health around water issues, and the continued economic growth of nations while investing in water crisis solutions.

\subsection{The Purpose of International Water Sector Aid}

\subsubsection{Altruistic}

As discussed in hypothesis 3, if international aid is altruistic, we would expect the amount of aid a nation receives would be proportional to their need. The water stress index ranges from 0 to 5 with 0 indicating no water stress and 5 indicating extreme competition for water resources. If aid is altruistic, we would expect more aid to go to nations with high levels of water stress. I find that a nation's water stress level is negatively correlated with the number of projects it has received in the water supply and sanitation sector (Pearson's $r=-0.19$ ). If we focus on the total funding amount (constant USD), instead of number of projects, I find a slightly positive relationship between funding amount and a nation's water stress level (Pearson's $r=0.07$ ). Bivariate ordinary least squares $(\mathrm{OLS})$ regression reveals no significant relationship between funding amount and water stress $(\mathrm{p}=.404)$. However, OLS regression shows that the negative relationship between total projects and water stress is negative and significant $(-25.85 ; \mathrm{p}<.05)$, indicating that for every 1 unit increase in water stress, a nation received $\sim 26$ fewer projects. These results contradict supporters of the aid as altruism discourse as nations with the greatest water stress actually receive less funding than their less needy peers.

While I find little evidence to support the hypothesis that international aid is altruistic based on water stress, hypothesis 4 questions whether projects are more holistic/complex. To determine this, I proxy complexity with the number of themes a project addresses. Simple projects address a single focus, while complex projects can address all four themes simultaneously. My analysis finds that only 2,770 (6.59\%) of the 42,060 projects address all four (human development, economic development, environmental concerns, and technical expertise) themes simultaneously. Over $40 \%$ of projects address only 1 theme, with human development being the most common theme. Table 2 provides a summary of the number of themes in each project. This evidence also shows little support for the hypothesis that international aid is altruistic, because only $\sim 6 \%$ of all water supply and sanitation sector projects address all four themes simultaneously, while most projects only address 1 or none of these concerns.

Table 3. Water Supply and Sanitation Sector Projects by Number of Themes Addressed

\begin{tabular}{ccc}
\hline Number of Themes & Total Projects & Percent \\
\hline 0 & 3,626 & 8.62 \\
1 & 16,955 & 40.31 \\
2 & 12,452 & 29.61 \\
3 & 6,257 & 14.88 \\
4 & 2,770 & 6.59 \\
\hline Total & 42,060 & 100 \\
\hline
\end{tabular}

\subsubsection{Self-serving}

The next set of hypotheses interrogates whether the purpose of international water aid is self-serving for the lenders. Swiss (2017) asserts that if international aid is intended to benefit the senders, then more projects would be concentrated in democratic countries and nations with high levels of trade. OLS regression reveals a negative and statistically significant relationship between a nation's level of democracy and the number of projects in the water sector it receives $(-31.41 ; \mathrm{p}=.001)$, indicating that for every unit increase in democracy, a country received 31 fewer projects, on average. However, this pattern does not hold for funding amount, as the relationship between democracy and amount funded is not significant. This suggests contradictory support for the democracy hypothesis, while democratic nations receive fewer projects, on average, than less democratic countries, the monetary value of those projects is not significantly different among more or less democratic nations. These results diverge from the expectations of the aid as self-interest discourse since we would expect democratic countries to receive more projects and greater funding than their non-democratic peers. 
The relationship between trade and international aid tells a different story. Trade is negatively correlated with both total projects and funding amount (Pearson's $r=-0.32 ;-0.29)$. OLS regression demonstrates that this relationship is statistically significant for number of projects $(-1.73 ; \mathrm{p}<.001)$, and for funding amount $(-2.84 ; \mathrm{p}<.001)$. These results indicate that for every $1 \%$ increase in trade ( $\%$ gdp), a nation received 2 fewer projects and $\$ 28.4$ million less. From this, I conclude that there is no support for the hypothesis that international aid is self-serving.

In addition to Swiss' (2017) measures of democracy and trade, I assert that international aid is self-serving if the projects are less complex and have fewer overlapping themes. Nations that lend for self-gain should be less concerned with having holistic, complex projects that address the problems facing receiving nations, instead focusing on building relations with the receiver country, showing that they are contributing with window dressing projects. Table 2 shows that the largest proportion of projects only address 1 theme. This would lend some support to the hypothesis that international aid is self-serving. However, the complete analysis shows that it may not be that simple, as there was contradictory support for the democracy hypothesis, and no support for the trade hypothesis.

\subsubsection{Global Embeddedness}

The final debated purpose of international aid proposed by Swiss (2017) is that international aid strengthens global embeddedness. Support for this hypothesis would find that nations with greater connection to world polity, as measured through NGO memberships, should receive more projects and greater funding than nation's with fewer NGO's. There is a significant positive relationship between NGO membership in a nation and the total amount of funding they received between 1950 and $2013(1.39 ; \mathrm{p}<.001)$. This suggests that for each additional NGO in a nation, that nation received, on average, $\$ 1.39$ million more. This relationship lends strong support to the global embeddedness hypothesis because nations with more NGOs received significantly more money in the water sector.

To further test whether the purpose of international aid is about global embeddedness, I determine how many projects addressed human rights, women's empowerment, and environmentalism, as these three concepts represent strong global scripts aimed at the proliferation of these as global norms (Schofer and Hironaka 2005; Shandra et al. 2008). My analysis shows that only 620 projects (1.5\%) have any mention of "human rights", while $111(<1 \%)$ mention "well-being" in their project descriptions. Another global norm that should have seen an increase in recent years is women's empowerment. However, only 162 projects discuss women's empowerment as a goal or outcome of the project. These scant results suggest that these specific global scripts have not penetrated the world of international water aid. One exemplary project, UNICEF-Academia-Private Sector Partnership Project, addresses multiple global scripts. It states,

"Human rights based approach in programming form the core framework for the project and it will be integrated and modified to all activities including the partnership model. Gender equality and reduction of inequality forms the core principles and attention is placed on addressing needs and capacity of girls and female entrepreneurs and ensuring equal opportunity to participate" (AidData 2017; project 906000871282).

This project discusses human rights, well-being, female empowerment, and equality, representing international water aid focused on fulfilling these global scripts. Unfortunately, this project is one of the few that explicitly addresses these issues.

However, further evidence for global embeddedness may be found by tracing the spread of environmentalism and NGOs in water supply and sanitation sector projects. 7,266 projects (17.3\%) explicitly address the environment or environmental concerns of water development. In addition, 8,767 projects (20.8\%) directly discuss NGOs in their descriptions. The majority of these projects simply state that they are for "support to national (regional, or local) NGOs activities" (i.e. AidData 2017; project 108459591; project 95553093). These results seem to suggest that NGOs and the environment may play an important role in international water lending. This, paired with the significant relationships between a nation's NGO memberships and the amount of money it has received, lends some support to the hypothesis that the purpose of international water aid is about global embeddedness.

This analysis suggests that there is no single purpose of international aid, but that aid senders make up a heterogenous group with different and often competing purposes. This competition and lack of cohesiveness amongst aid senders may cause water crisis solutions to fail, especially if some projects undermine the goals of others.

\subsection{Calls for Action; Improving International Water Sector Aid}

In addition to the debate concerning the purpose of international development aid, researchers and practitioners have been calling for three major changes in aid practices; aid should be collaborative and polycentric (using input from governments, local groups, NGOs, and multinational organizations), aid should be holistic (addressing social, economic, and environmental issues simultaneously), and aid should include long-term monitoring, evaluation, and critical reflection (to improve upon those projects that have worked in the past and to adjust or discard those solutions that haven't). The second part of this content and trend analysis will begin to interrogate whether these three changes have been taking place. 


\subsubsection{Collaboration and Polycentric Governance}

Scores of researchers and practitioners alike have emphasized the importance of polycentric collaboration in international aid. Not only is it vital that there is input at all levels (local, community, NGO, national government, and multinational organization), but it is equally important that there is effort to collaborate across levels. The content analysis allows me to search all water sector project descriptions for evidence of this collaboration. First, there are zero uses of any form of the word 'polycentric' in the entire corpus. This suggests that the call from researchers for polycentric governance has not reached those groups that are responsible for international water aid. Collaboration, in all its forms, on the other hand, came up in 623 projects $(1.5 \%)$. While the number of projects specifically discussing collaboration is low, there may still be hope, as the proportion of collaboration projects has increased from $<1 \%$ of projects before 2010 to $\sim 3 \%$ of projects in the years after 2010. Collaborative projects are vital, as they demonstrate a commitment to working together with the community to address water needs. For example, project 98681647 states that "AHJASA will collaborate with 30 communities toward the development of systems supplying water safe for human consumption" (AidData 2017). Perhaps the world of international water aid is slowly answering the call for more collaboration.

In addition, I searched for other key phrases in the hopes of finding more support that international water aid is becoming more collaborative. Specifically, I looked for projects that used words like local, communal, community, and grassroots. There were very few projects addressing grassroots (123 projects) or communal issues (507). However, there were abundant examples of projects that focused on local $(4,101 ; 9.8 \%)$ and community issues $(5,872 ; 14 \%)$. While there is no guarantee that these projects had polycentric collaboration, it is still a hopeful sign that there is some focus addressing water issues from a local and community perspective. One of the goals of project 40327695, Sustainable Environmental Management for Sixaola River Basin, is to "strengthen the capacity of the local and indigenous communities living in the buffer zones... of the protected areas" (AidData 2017). Other projects "support local innovation in sustainable water management" (AidData 2017; project 40343999) or "help raise the living standards of ... the country's most impoverished communities" (project 2432761).

However, there are two signs that these efforts have not gone far enough. The first sign is that $~ 10-14 \%$ of projects is still critically low given the wide call for collaboration, as this means that $85-90 \%$ of projects still do not address problems specifically for local and community populations. The second sign is that there has not been an increase in focus on local and community projects over time, as the ratio of local/community projects to all others has not increased over time. Therefore, while there is evidence of some efforts at collaboration and polycentric governance in international water aid over time, it still appears as though a lot more effort is needed to meet calls for collaboration.

\subsubsection{Long-Term Monitoring and Evaluation}

A second vital aspect of international water aid is long-term monitoring, evaluation, and critical reflection for existing projects. The only way to improve our water development outcomes is to assess the failure and success of past interventions (Gleick, 2003; Meinzen-Dick, 2007). To determine whether there are efforts to do that, I searched the long descriptions of 42,060 projects for any mention of monitoring, evaluation, upkeep, and reflection. Variants of monit* were the most common (1,804 projects; 4.3\%). Project 2416886, the Bishkek and Osh Urban Infrastructure Project, includes "the creation and maintenance of a system to continuously monitor and evaluate the performance and results of the project" (AidData 2017). Sadly, less than 5\% of all projects mention any form of monitoring, indicating that monitoring is uncommon. Variants of evalu* were the second most common key words, appearing in 1,023 projects (2.4\%). A great example of evaluation in a project states that the project intends to "strengthen their capacity to monitor and evaluate adaptation to climate change... through better informed policy decisions and planning" (AidData 2017; project 50059837).

While monitoring and evaluation appeared in $4.3 \%$ and $2.4 \%$ of projects respectively, the other words to represent critical reflection were extremely scarce. Of the 139 uses of any variant of the word 'reflect' in the corpus, zero of them were in the context of critical reflection of the current or previous projects. Typical usage of the word reflection states "the cost differences were a reflection of the doubling of fuel costs" (AidData 2017; project 2417169). The use of reflection and its variants was mostly used to discuss how one aspect of the project reflects another aspect of the project or reflects on finances. Usage of words like follow-up (76 projects) and upkeep (8 projects) were so rare as to be almost non-existent. It is unfortunate that these themes are not more common among water development projects, as critical reflection, monitoring, and evaluation can help us to assess and improve our ability to solve the world's (and its communities) water crises.

From an empirical analysis of all existing water supply and sanitation sector projects, the call for greater monitoring, evaluation, and reflection is more urgent than ever. International water development has skyrocketed after 2000, but our efforts may be futile if we do not analyze the successes and failures of those that came before. There is no indication or evaluation of successful and failed projects, nor is there any indication of how a new project can be successful. Future international water aid should take a critical look at the past to determine how best to proceed in the future. 


\subsubsection{Holistic Water Aid}

The call for holistic water aid is the most common strategy for improving international water development in the literature (Huitema et al. 2009; Mukheibir 2010). In general, this calls for international aid projects to address facets of social, economic, and environmental issues simultaneously. Only 2,528 ( 6\%) projects addressed social (human development), economic, and environmental concerns within their long descriptions. Even more worrying is the fact that it is difficult to find projects among them that truly encompass a holistic outlook that adequately addresses the social, economic, and environmental concerns of the receiving nation or community. Project 2418197, public works and social development supplemental project, comes close to this goal, stating that it will "ensure sustainable use of the already established social and economic infrastructure... fund the completion of vital ... development programs in the poorest neighborhoods... improve and expand their existing street systems, water supply and sanitation services, and primary education... aimed at creating job opportunities for the poorest segments of the local population" (AidData 2017). While this project does take a holistic approach, its stated commitment to environmental protection is fairly weak, with only one mention of sustainable use of existing resources. Project 74874599 from Canada to Cameroon is another example of a holistic water development project, stating that it will "Participate in the fight against poverty by improving the conditions of life of the most [disadvantaged] rural populations of Cameroon... Sustainable improvement in access to drinking water... The sustainability of the system of maintenance of the water points... guarantee sufficient and sustainable supply of drinking water and sanitation [translated from French using Google translate]" (AidData 2017). However, where the previous project was lacking in environmental awareness, project 74874599 lacks a focus on economic concerns.

While there are pockets of international water aid ( $6 \%)$ that are concerned with providing holistic water development to address the concerns of the receiver country, even among these it is rare for projects to truly encompass all three tenets of the sustainable development goals (social, economic, and environmental). What is even more concerning is that the proportion of projects addressing 3 or 4 themes has decreased over time. In the 1980's, between 20-30\% of all projects had all four themes, but this number dropped to between $2-6 \%$ in the past decade. This may indicate that the calls for a more holistic approach in international development are not being heeded by the lending organizations. It is more necessary now than ever to take the complex needs of receiving populations into account when attempts are made to solve their water development issues.

\section{Discussion and Conclusion}

\subsection{Theoretical Contributions}

Researchers highlight the developmental benefits of increasing access to water, and the environmental damage associated with decreasing water supplies. In addition, there are several debates in the international development literature concerning the purpose and effectiveness of global aid practices. While some researchers debate the intention of global aid, focusing on altruistic and social-political explanations (Lumsdaine 1993; Opeskin 1996), several researchers are concerned with the collaborative and holistic nature of projects (Huitema et al. 2009; Mukheibir 2010; Pahl-Wostl et al. 2012). Still, several studies are concerned that if projects are not properly implemented and evaluated, they will fail to reach their intended goal (Gleick, 2003; Meinzen-Dick, 2007). Building on these debates and previous research, the present study focuses on the water sector, as several development and environmental conditions hinge upon its effectiveness. While global access to water is increasing, water resources are decreasing at an alarming rate, and little is known about how these lending practices have changed over time, what they focus on, and if they are likely to address both the developmental and environmental water crises simultaneously. Drawing on several debates in the international development literature, I use computational content analyses to begin to find answers to these questions.

Diverging from previous research, I consider not only the intention of water sector aid, but also if projects are holistic, address multiple issues at once, and integrate monitoring efforts to ensure the success of projects using a novel research design to encompass an entire lending sector. I push forward metabolic rift theory to consider the reciprocal destruction of human needs and environmental requirements. I find that very few projects address both human development and environmental themes simultaneously, which suggests that the two water crises are far from being resolved. Unfortunately, the intended benefits of increasing access to water may be undoing efforts to conserve water. It therefore follows that efforts to decrease water scarcity may make it more difficult for populations to have access to water, which may critically undermine decades of development lending.

Scholars in the sociology of development have long debated the intention of international aid. Swiss (2017) proposes three main discourses, aid as altruistic, aid as self-serving, and aid as global embeddedness. I find the most support for theories of global embeddedness, compared to perspectives concerning altruism or self-serving behavior. Although I find more support for theories of global embeddedness, diverging from previous research (Swiss 2017), only one-fifth of projects support an embeddedness purpose. Therefore, contrary to previous research my findings suggest that there is no overarching purpose of international aid, but that aid senders make up a heterogenous group with different and often 
competing purposes. Unfortunately, a lack of cohesion amongst aid senders may result in project failure if some projects undermine the goals of others. My second set of hypotheses addresses concerns in IMWR research that aid projects are not holistic, collaborative, or self-reflexive. My findings support these assertions, with $\sim 6 \%$ of projects covering social, economic, and environmental themes, $1.5 \%$ of projects discussing cooperation of any kind, and $<5 \%$ of projects having any type of monitoring or evaluative system in place. While I find some evidence of collaboration and polycentric governance in international water aid over time, it still appears as though a lot more effort is needed to meet researchers and practitioners' calls for cooperation. There is also little evidence to support any increase in proposed project monitoring, evaluation, follow-up, and reflection. My findings converge with previous research calling for more holistic projects and evaluation (Gleick, 2003; Mukheibir 2010).

\subsection{Methodological Contributions and Limitations}

This study represents the first attempt at an analysis of the intentions and effectiveness of international water lending using all 40,000+ water sector projects to date. The inductive and deductive methods used through computational and analog content analysis allows the researcher to get a clear insight into the discourses international water lenders utilize to explain and justify their investments. This novel approach may be useful for analyzing other aspects of international development through a systematic analysis of aid in other sectors or content analysis of international treaties and regulations.

Despite the findings of this study, there are limitations. First, while the present study draws on water sector lending as a case study of lending, more research must be done to see if other sectors follow similar patterns. Although global water aid does not address water crises as interconnected, perhaps other sectors have taken more measurable holistic approaches. Therefore, future research may create aid datasets beyond the water sector, perhaps focusing on food security and agriculture. This seems to be a prime area of analysis because as agriculture increases in sophistication, fertilizers and pesticides are more utilized (Shorette 2012). Unfortunately, such agrochemicals tend to reduce soil quality, making it more difficult for crops to grow overtime, which limits the amount of food available as agricultural land area becomes increasingly degraded (Shorette 2012). Therefore, while world hunger is decreasing, our means that helped the world achieve these goals are degrading the soil, leaving land less suitable for crops. In sum, researchers may investigate if agricultural aid is addressing both world hunger and land degradation issues. Second, as with all content analyses, the present analysis may appear discursive and disconnected from actual water projects on the ground. However, at its worst the data used in this study represent descriptions of actual projects and intentions. As we know from previous research on aid, projects often fail to meet their goals or are too small in scope to make a large enough impact on its intended target (Barlow 2014; Mukheibir 2010). Therefore, if anything, the findings from this analysis should be more optimistic compared to what results from poor project implementation. In short, rhetoric represents intentions, and while those intentions may not correspond to well-implemented actions, at the very least they show dismal hope for the success of water sector lending at resolving the two water crises concomitantly. Therefore, from the findings it appears that there is decoupling between the rhetoric of sustainable development goals and its implementation.

\subsection{Policy Recommendations}

Based on the findings of this study, there are a few policy recommendations. If international water aid does not take the broad calls for improvement from researchers and practitioners, I do not foresee a solution to the environmental and human water crises. Going forward, lenders should focus on making international water development more holistic, polycentric, and self-monitoring. Without consideration for what has worked and failed in the past, the needs of local/community, as well as national needs, and a focus on the social, economic, and environmental concerns of those in need, I fear that some projects may do even more harm than good. Non-holistic projects, especially those that do not consider past failures, have a great capacity for harm in those sectors they fail to address. In addition, receiver nations may aim to become more involved with the planning and implementation of water aid projects at the national, NGO, and local level, to increase collaboration and ensure the needs of the population and environment are met.

One indisputable conclusion transcends the fallbacks of this study: while we must continue to fight to bring water to populations, these efforts may be in vain if we do not analyze the factors that lead to more effective and sustainable increases in access to improved water and sanitation and environmental protection. For the management of this water crisis to be successful, scholars and practitioners need to combine knowledge to ensure the ethical and sustainable implementation of lending and development.

\section{Acknowledgements}

This research was supported by the National Science Foundation Graduate Research Fellowship. The author would like to thank Rebekah Burroway, Jason Jones, Ian Roxborough, Michael Schwartz, Mark Montgomery, and Jamie Sommer for their suggestions and advice. 


\section{References}

AidData. (2017). International Aid to the Water Supply and Sanitation Sector from all Lenders. [Data File]. Retrieved from http://www.aiddata.org/dashboard

Alesina, A., \& Dollar, D. (2000). "Who Gives Foreign Aid to Whom and Why?" Journal of Economic Growth, 5(1), 33-63. https://doi.org/10.1023/A:1009874203400

Bakker, K. (2014). "The Business of Water: Market Environmentalism in the Water Sector." Annual Review of Environment and Resources, 39, 469-494. https://doi.org/10.1146/annurev-environ-070312-132730

Barlow, M. (2014). Blue Future: Protecting water for people and the planet forever. Toronto, Canada: House of Anansi Press.

Black, M., \& King, K. (2009). The Atlas of Water: Mapping the World's Most Critical Resource. Berkeley, CA: University of California Press.

Carment, D., Samy, Y., \& Prest, S. (2008). "State Fragility and Implications for Aid Allocation: An Empirical Analysis." Conflict Management and Peace Science, 25(4), 349-373. https://doi.org/10.1080/07388940802397509

Clausen, R., \& Clark, B. (2005). "The Metabolic Rift and Marine Ecology: An Analysis of the Ocean Crisis Within Capitalist Production.” Organization \& Environment, 18(4), 422-444. https://doi.org/10.1177/1086026605281187

Coburn, C., Restivo, M., \& Shandra, J. M. (2015). "The African Development Bank and Women's Health: A Cross-National Analysis of Structural Adjustment and Maternal Mortality." Social Science Research, 51, $307-321$. https://doi.org/10.1016/j.ssresearch.2014.09.007

Desai, S., \& Alva, S. (1998). "Maternal Education and Child Health: Is There a Strong Causal Relationship?" Demography, 35(1), 71-81. https://doi.org/10.2307/3004028

Feeny, S., \& McGillivray, M. (2009). "Aid Allocation to Fragile States: Absorptive Capacity Constraints." Journal of International Development, 21(5), 618-632. https://doi.org/10.1002/jid.1502

Feldman, D. L. (2012). Water. Malden, MA: Polity Press.

Fink, G., Gunther, I., \& Hill, K. (2011). "The Effect of Water and Sanitation on Child Health: Evidence from the Demographic and Health Surveys 1986-2007." International Journal of Epidemiology, 40, 1196-1204. https://doi.org/10.1093/ije/dyr102

Foster, J. B. (1999). "Marx’s Theory of Metabolic Rift: Classical Foundations for Environmental Sociology.” American Journal of Sociology, 105(2), 366-405. https://doi.org/10.1086/210315

Freedom House. (2017). Political Rights and Civil Liberties. [Data File]. Retrieved from https://freedomhouse.org/report/freedom-world-2016/table-scores

Galaz, V., Moberg, F., Olsson, E. K., Paglia, E., \& Parker, C. (2011). "Institutional and Political Leadership Dimensions of Cascading Ecological Crises." Public Administration, 89(2), 361-380. https://doi.org/10.1111/j.1467-9299.2010.01883.x

Gibson, C. (2012). "Making Redistributive Direct Democracy Matter: Development and Women's Participation in the Gram Sabhas of Kerala, India." American Sociological Review, 77(3), 409-434. https://doi.org/10.1177/0003122412442883

Gleick, P. H. (2003). "Global Freshwater Resources: Soft-Path Solutions for the 21st Century." Science, 302(5650), 1524-1528. https://doi.org/10.1126/science.1089967

Hertz, E., Herbert, J. R., \& Landon, J. (1994). "Social and Environmental Factors and Life Expectancy, Infant Mortality, and Maternal Mortality Rates: Results of a Cross-National Comparison." Social Science and Medicine, 39(1), 105-114. https://doi.org/10.1016/0277-9536(94)90170-8

Homer-Dixon, T., Walker, B., Biggs, R., Crépin, A. S., Folke, C., Lambin, E. F., Peterson, G. D., Rockstrom, J., Scheffer, M., Steffen, W., \& Troell, M. (2015). "Synchronous Failure: The Emerging Causal Architecture of Global Crisis." Ecology and Society, 20(3), 6. https://doi.org/10.5751/ES-07681-200306

Huitema, D., Mostert, E., Egas, W., Moellenkamp, S., Pahl-Wostl, C., \& Yalcin, R. (2009). “Adaptive Water Governance: Assessing the Institutional Prescriptions of Adaptive (Co-)Management from a Governance Perspective and Defining a Research Agenda." Ecology and Society, 14(1), 26. https://doi.org/10.5751/ES-02827-140126

Linton, J. (2010). What is Water? The History of a Modern Abstraction. Vancouver, Canada: UBC Press.

Lumsdaine, D. H. (1993). Moral Vision in International Politics: The Foreign Aid Regime, 1949-1989. Princeton, N.J.: Princeton University Press.

Meinzen-Dick, R. (2007). "Beyond Panaceas in Water Institutions." Proceedings of the national Academy of sciences, 104(39), 15200-15205. https://doi.org/10.1073/pnas.0702296104

Montgomery, M. A., \& Elimelech, M. (2007). "Water and Sanitation in Developing Countries: Including Health in the 
Equation." Environmental Science and Technology, 41(1), 17-24. https://doi.org/10.1021/es072435t

Mukheibir, P. (2010). "Water Access, Water Scarcity, and Climate Change." Environmental Management, 45(5), 1027-1039. https://doi.org/10.1007/s00267-010-9474-6

Opeskin, B. R. (1996). "The Moral Foundations of Foreign Aid." World Development, 24(1), 21-44. https://doi.org/10.1016/0305-750X(95)00118-V

Pahl-Wostl, C. (2015). Water Governance in the Face of Global Change: From Understanding to Transformation. Cham, Switzerland: Springer International Publishing. https://doi.org/10.1007/978-3-319-21855-7

Pahl-Wostl, C., Lebel, L., Knieper, C., \& Nikitina, E. (2012). "From Applying Panaceas to Mastering Complexity: Toward Adaptive Water Governance in River Basins." Environmental Science \& Policy, 23, 24-34. https://doi.org/10.1016/j.envsci.2012.07.014

Pimentel, D., Houser, J., Preiss, E., White, O., Fang, H., Mesnick, L., Barsky, T., Tariche, S., Schreck, J., \& Alpert, S. (1997). "Water resources: agriculture, the environment, and society." BioScience, 47(2), 97-106. https://doi.org/10.2307/1313020

Sachs, J. (2015). The Age of Sustainable Development. Columbia, NY: Columbia University Press. https://doi.org/10.7312/sach17314

Schofer, E., \& Hironaka, A. (2005). "The Effects of World Society on Environmental Protection Outcomes." Social Forces, 84(1), 25-47. https://doi.org/10.1353/sof.2005.0127

Shandra, C. L., Shandra, J. M., \& London, B. (2011). "World Bank Structural Adjustment, Water, and Sanitation: A Cross-National Analysis of Child Mortality in Sub-Saharan Africa." Organization \& Environment, 24(2), 107-129. https://doi.org/10.1177/1086026611413931

Shandra, C. L., Shandra, J. M., \& London, B. (2012). "The International Monetary Fund, Structural Adjustment, and Infant Mortality: A Cross-National Analysis of Sub-Saharan Africa." Journal of Poverty, 16, 194-219. https://doi.org/10.1080/10875549.2012.667059

Shandra, J. M., Restivo, M., \& London, B. (2008). "Non-Governmental Organizations and Deforestation: Reconsidering the Cross-National Evidence." International Review of Modern Sociology, 34(1), 109-132.

Shiva, V. (2002). Water Wars: Privatization, Pollution, and Profit. Berkeley, CA: North Atlantic Books.

Shorette, K. (2012). "Outcomes of Global Environmentalism: Longitudinal and Cross-National Trends in Chemical Fertilizer and Pesticide Use.” Social Forces, 91(1), 299-325. https://doi.org/10.1093/sf/sos053

Swiss, L. (2017). "Foreign Aid Allocation from a Network Perspective: The Effect of Global Ties." Social Science Research, 63, 111-123. https://doi.org/10.1016/j.ssresearch.2016.09.011

Tacconi, L., \& Tisdell, C. (1993). "Holistic Sustainable Development: Implications for Planning Processes, Foreign Aid, and Support for Research.” Third World Planning Review, 15(4). https://doi.org/10.3828/twpr.15.4.n020t7281k1221m0

Taylor, P. L., \& Sonnenfeld, D. A. (2017). "Water Crises and Institutions: Inventing and Reinventing Governance in an Era of Uncertainty." Society and Natural Resources, 30(4), 395-403. https://doi.org/10.1080/08941920.2017.1274208

UNICEF and World Health Organization. (2015). Progress on Sanitation and Drinking Water: 2015 Update and MDG Assessment. Geneva, Switzerland: WHO Press.

World Bank. (2003). “Water, Sanitation \& Hygiene.” At a Glance. Washington, DC: World Bank Group.

World Bank. (2017). World Development Indicators. [Data File]. Retrieved from http://data.worldbank.org/indicator.

World Resources Institute. (2017). Water Stress. [Data File]. Retrieved from http://www.wri.org/our-work/project/aqueduct

York, R., Rosa, E. A., \& Dietz, T. (2003). "Footprints on the Earth: The Environmental Consequences of Modernity." American Sociological Review, 68(1), 279-300. https://doi.org/10.2307/1519769

\section{Copyrights}

Copyright for this article is retained by the author(s), with first publication rights granted to the journal.

This is an open-access article distributed under the terms and conditions of the Creative Commons Attribution license which permits unrestricted use, distribution, and reproduction in any medium, provided the original work is properly cited. 